\title{
An Annotated Bibliography of the Books on Translation Studies published in 2017
}

DEEPA $V$.

DeCKeRT, MikolaJ. (ed.). 2017. Audiovisual TranslationResearch and Use. New York: Peter Lang.

As the title indicates, this book focuses on the various researches happening in the area of Audiovisual Translation (AVT) and its applications in the society. Deckert explores different approaches to AVT, both traditional and modern, the challenges it faces, emerging research methodologies in AVT, AVT training and so on. It also looks at the politics and agendas guiding the AVT through different case studies, accessibility issues and also the possibilities of its applications in the classrooms. In short, the book aims to map the gap that exists between theory and practice in the field of Audiovisual Translation.

MundAy, JeREMy \& MEIFANG ZhANG (eds.). 2017. Discourse Analysis in Translation Studies. Amsterdam: John Benjamins Publishing Company.

This edited volume contains eight articles by eminent scholars across the globe specialised in the area of discourse analysis. These articles focus on different themes and sub-themes of discourse analysis such as manifestations of power and ideology in discourse practices, textuality, linguistic factors and so on. It explores the growth of discourse analytic approach in Translation Studies since the 1990s by looking at new trends in this area, contemporary research trends, its scope and challenges and also charts out its future directions.

DWYER, TeSSA. 2017. Speaking in Subtitles: Revaluing screen translation. Edinburgh: Edinburgh University Press. 


\section{Deepa V.}

Dwyer, in this work, explores how the dominance of English in screen media across the globe has changed media experience today, thus, making translation central to screen media analysis. This work analyses how translation is a significant factor in the selection and distribution of films or programmes, how they are seen, framed and understood. Yet, the role of translation is often devalued and ignored in media studies. This work aims to address the issue of screen translations by looking at operations of dubbing, subtitling, media piracy, fansubbing, streaming and subbing. She also looks into the internal value politics within these domains.

WOODSWORTH, JUDITH. 2017. Telling the Story of Translation: Writers who Translate. London: Bloomsbury.

Judith Woodsworth, in this book, explores the largely ignored or unrecognised contributions of the three British authorsBernard Shaw, Gertrude Stein, and Paul Auster. Though they were well known and well received as authors, their contributions in the domain of translation remain unexplored both by literary scholars as well as translation studies scholars. Woodsworth analyses how translation occupies an essential place in their literary careers, how they have engaged with translation and how an exploration of these aspects in their careers can help us understand the intersection of language and culture in the modern era.

Maria Lin Moniz And AleXANDRA Lopes (eds.). 2017. The Age of Translation: Early $20^{\text {th }}$ century Concepts and Debates. New York: Peter Lang.

As the title indicates, this volume examines the developments of the first half of the twentieth-century and explains how that has given shape to certain conceptions, misconceptions, discourses, practices, possibilities and interdictions in the fields of literature, communication and culture. It also looks 
into how translation is central in any mapping of the twentiethcentury both conceptually and pragmatically. The eleven essays comprising this volume focus on diverse topics such as war and propaganda, gender and literacy, censorship and their impact on literature and translation. These articles reflect on how individual socio-political events, ideologies, stereotypes, prejudices and the like shape translation and are in turn shaped by translation.

LEW N. Zybatow, ANDy Stauder AND Michael UsTASZEWSKI (eds.) 2017. Translation Studies and Translation Practice: Proceedings of the $2^{\text {nd }}$ International TRANSLATA Conference, 2014. New York: Peter Lang.

This book contains proceedings in two volumes. The first volume offers plenary talks, three workshops (humour \& legal translation, human-machine interaction in translation) and a few sessions on different areas and aspects of translation. The second volume contains papers from the remaining sessions of the conference. These papers focus on translation proper professional translation and interpreting in all kinds and varieties. Each session covers diverse areas such as audiovisual translation, computer-aided translation, interpretation, translation practice, the relation between theory and practice, literary translation, translation process, translation competence and so on.

Khan, TARiQ (ed.) 2017. History of Translation in India. Mysuru: National Translation Mission.

History of Translation in India attempts to trace translation practices and traditions in India. It is a collection of 19 articles that deal with translation traditions from different languages such as Telugu, Odia, Kannada, Hindi, Nepali, Assamese, Maithili, Marathi, Malayalam, and so on. These articles do not give a mere descriptive historical account; instead, they 


\section{Deepa V.}

critically engage the issues related to the role of translation in shaping the literary traditions and cultural identities, the relation between translation and literature, translation and colonial power, and so on.

O'CONNOR, ANNE. 2017. Translation and Language in Nineteenth-Century Ireland: A European Perspective. London: Palgrave Macmillan.

Anne O'Connor explores the impact of European culture on Irish society through examining translations of modern European languages into English in $19^{\text {th }}$ century Ireland. She uses translation as a paradigm to analyse transnational trends with the focus on the European movement of people, ideas and texts and the connection between Ireland and Europe through these transnational transfer. It also looks at questions of power, gender, and the role of religion and so on in the process of selection and reception of translated works.

TAMBOURATZIS, GEORGE.; VASSILIOU MARINA.; AND SOFIANOPOULOS SOKRATIS. 2017. Machine Translation with Minimal Reliance on Parallel Resources. Switzerland: Springer.

This work is an outcome of the PRESEMT project, a collaborative effort initiated by Institute for Language and Speech Processing, Athena. It attempts to circumvent the requirement for specialised resources and tools to support the creation of MT systems for diverse language pairs without constraints. This volume details its development history, its advantages and disadvantages, PRESEMT methodology, its working method and the possibilities for implementing it.

VAlERO-GARCÉS, CARMEN AND REBECCA TIPTON (eds.). 2017. Ideology, Ethics and Policy Development in Public Service Interpreting and Translation. Bristol: Multilingual Matters. 
This edited volume examines social, political and ethical issues in policy-making and public service interpreting. The chapters explore ideologies of recruitment, positioning, discourses of professionalisation and the ethics and politics of recognition. It also evaluates the relation between recent theorisations of interpreter and translator ethics in the academia and practice in the field. It also provides case studies of interpreting in settings such as courtrooms, with asylum seekers, refugees and trauma survivors and brings in a new perspective on the use of training interpreters for such social imperatives.

House, Juliane. 2018. Translation: The Basics. London: Routledge.

This work provides a user-friendly and comprehensive introduction to translation discussing basic ideas and trends in Translation Studies. The book has four parts that explore the nature and aspects of translation; theoretical issues and concepts; new trends in Translation Studies; the role of translation in real life, especially in language learning and teaching. Juliane looks at translation as a cross-cultural and inter-cultural phenomenon and addresses questions of gender, power, culture and ideology in the act of translation. It is also important to note that the actual publication year of this book may be 2018 . 